\title{
Globalization as Politics of Neo-Colonization: Teaching English language in Higher Education in Nepal
}

\author{
- Raj Kumar Sharma
}

\begin{abstract}
:
This article briefly discusses colonial history as background knowledge and then tries to define globalization covering some of the issues of globalization. Through defining and covering some issues regarding globalization, it enters into the issue of neo-colonization. After that, it gives a brief glimpse that how the teaching English language in higher education of Non-western has blended the politics of Neo-colonization.
\end{abstract}

Key words: Globalization, Colonization, Neo-colonization, Curriculum, University, and Teaching method.

\section{Globalization: Politics of Neo-Colonization}

The term globalization refers to the universe as a single village. Single village became possible because of the help of advanced information and technology. McLuhan and Fiore (2013) opine "Ours is a brand new world of allatoncenss."Time" has ceased, "Space has vanished". We now live in a global village... a simultaneous happening" (Lane, 2013, p. 167). In postmodern era, because of advanced information and technologies, time has ended and space has disappeared. "Oxford Advanced Learner's Dictionary" ( $8^{\text {th }}$ eds.) defines globalization as "the fact that different cultures and economic systems around the world are becoming connected and similar to each other because of the influence of large MULTINATIONAL companies and of improved communication" (p.659). Because of the large scale of international companies and advanced modern technology different cultures and economic systems around the world are becoming interconnected and are being influenced to each other. But its negative impact is upon developing countries' culture; because Europeans do not mimic the lifestyle and culture of non-European. Richard J Lane (2001) looks on globalization by judgmental eyes:

Globalization is a process that many thinkers regard as a new phenomenon, belonging to the world of postindustrial global flows of money, new high speed technologies that offers near-instantaneous data communications, and the global distribution of 
ideas, brands and ideologies be this through the dominance of "Western Capitalism", "Americanism", religious "fundamentalism (s)" and so on. (p. 56)

The concept of colonization has been substituted by the new political term globalization which has more negative impacts upon non-European than positive. For example, it is the new political way to distribute their ideas, brands, and ideologies which are the means to create domination upon non-European. Globalization is the good slogan to Europeans to dominate non-European countries through the high speed information technology. Globalization is regarded, Lann (2013) remarks, "as an adverse impact; for example, a Western product (such as a brandnamed drink) is consumed in the non-Western World at the expense of local product (such as locally produced tea) that was once seen as an important component of local identity" (p.860). Because of the negative impact of the globalization, local identities are in crisis. People are mimicking and using westerner's product forgetting their own local identities. In the context of Nepal, for example, people use drink expensive and unhealthy western's products like Coca Cola, Sprite forgetting to drink buttermilk. They wear European products, ignoring indigenous product. Most of Nepalese people wear coat, paint and tie instead of Daura and Surwal which is Nepali national uniform. It is the negative impact of globalization where western culture is dominating and colonizing upon Nepali culture. Because of globalization local identities are being lost.

Colonization was direct domination of developed and powerful European countries whereas neo-colonization is indirect domination of developed and powerful European and American countries over the developing country of world. In the history, European domination started in the late fifteenth century and continued it till 1930s. The European countries like Spain, France, England, Portugal and Netherlands were the main contenders for the plunder of natural and human resources and over the next few centuries' European empires extended themselves around the globe. During the nineteenth century, Britain appeared as the major powerful country, and by the turn of the twentieth century the British Empire colonized one quarter of the total world. In the colonial period, Europeans established their colonies in India, Australia, New Zealand, and Canada, Ireland, Africa and West Indies and ruled upon indigenous people according to their own interest. At that time, they directly plundered all natural and human resources as much possible, in this sense colonization is taken as direct domination and exploitation of European countries over developing countries.

After the World War II, colonized countries revolt against colonizer to gain independence. In this regard, Tyson (2008) writes, about British colonial domination, "continued until the end of World War II, when India gained independence in 1947, and other colonies gradually followed suit. By 1980s, Britain had lost all but a few of its colonial holding" (p. 366). After losing the direct colonial power, after World War II, they focused on to introduce the concept of globalization through which they are politically colonizing other countries. After that, till 
now, control of human and material resources is not done through direct military subjugation. However, they have been creating new form of colonization in the name of globalization.

The world is being reconstituted as a single social space and becoming more homogenized. The negative impact of globalization is that it is creating everything homogeneous, exterminating the heterogeneous and its distinct characteristics. Heterogeneity is being collapsed day by day because of globalization the items of local variants are increasingly fewer. In this regard, Timothy Brennan (2013) writes:

One ... the world is being more homogenized that we are seeing the creation of single, albeit hybridized, World culture whose pace of life, tests and customer-conditioned by a similar regime of commodities .... It could also be taken to mean that we are on the road to global political integration. It is worth recognizing, however, that it does not necessarily stipulate either of these positions. To say, "A single social space". . . and dynamic internal variations across an interconnected system or localities and regions. The key ... a governing logic or social tendency that brings all these localities and regions into a unity unknown before. (pp. 876-887)

As a result of globalization, the world is losing the local identity of diverseness. Day by day, local various diverse items that are related to local identity are being collapsed in the developing counties. Developing countries are compelled to follow the developed countries' notions of advanced communication technology such as, cars, computers and cellular phones. NonWestern world is facing the hegemonies regarding the advanced communication technology.

The notion of globalization is guided by international corporations rather than direct political influences and activities. The responsible factors for globalization are multinational companies of the West. Globalization, Sklair argues, "is not political factor but transnational corporations that are responsible for globalization, and therefore what is happening is deliberately outside political structures and even in opposition to them" (qtd. in Bernnan, p. 881). Multinational companies, financial and corporation companies are the means of neo-colonization. Globalization is the result of, Brenna (2013) insists, "development in technology, transportation and financial/corporate restructuring working in concert with an underlying ideology that is basically Americans" (p. 881). In this light globalization is being the means of colonization the developing countries. Developed countries have colonized to developing countries in the name of innovative technologies, transportation, and financial corporation. It pictures implicit ideology of colonizer in the age of the so-called globalization. Globalization is as Berman (2013) argues "largely fictive enterprise, either cynical or guilty of wishful thinking" (p.882). $\mathrm{He}$ is arguing that globalization as a threat for developing countries that is why we need to be cautious about its metamorphosis nature. 
The concept, neo-colonialism means implicit political as well as other domination of one nation over another nation. There are various means of neo-colonization. Neo-colonization is possible through the name of advanced science and technology, education, language, medicine and culture. However, it is a difficult job to describe the fact concept of neocolonialism. However, here neocolonialism means a planned policy of advanced nations to maintain their hegemony indirectly in developing countries through advanced science and technology, education, language, medicine and culture. In a sense, it is also simply a continuation of past practice of explicit influence of colonialism. Neocolonialism can be quite open and obvious, such as, Altbach (1995) argues "the distribution of foreign textbooks in the schools of a developing country. It is, however generally more subtle and includes the use of foreign technical advisors on matters of policy and the continuation of foreign administrative models and curricular patterns for schools" (p. 452). As Altbach's argument developing countries are relaying on developed country from various angles. Even in curriculum design, though they have sufficient local materials, developing countries are relying on the materials published by European and American countries. Neocolonialism Altbach (1995) insists "differs from traditional colonialism in that it does not involve direct political control, leaving substantial leeway to the developing country". (p.452). Developed countries are colonizing implicitly, therefore, it is partly planned policy of advanced nations to maintain their influence in developing countries.

\section{Politics of Neo-colonization in English Curriculum of Non-Western University}

Curriculum of most of (not all) English Department of non-western and non-American countries at universities are focused on only to prescribe European and American's philosophy, novel, poetry, drama, essay and short stories is another responsible tool that cultivate neocolonization. In the course of history of English literature, of course, prescription of some authentic text is required but these should not be totally domination of the European's texts in the name of authenticity. However, in the name of authentic materials, there should not be totally domination of English texts only because if the curriculum prescribed only English literature and philosophy it some extent defense of neo-colonization. Instead, it would be better to prescribe the texts that are written in sound English or the books that are translated into English language are better to prescribe to resist on neo-colonization.

Some of English Department at universities of Africa, Australia and Canada have been excluding unnecessary burden of European's books, prescribing their own writer's books written or translated into English language. Regarding the abolishment of the heap portion of European's texts from the curriculum, Thiong'o (1995) argues that; "We have argued the case for the abolition of the present Department of English in the College, and the establishment of a Department of African Literature and Languages" (p. 441). Africans are establishing Department of African Literature and Language to abolish the unnecessary burden of European domination over their curriculum. This is the best way to promote their own literature, 
language and cultures as well as identity. But quite opposite to them, our universities courses of English Departments are focused on only English literature which is shameful job in this neo-colonization era.

In the context of Nepal, curriculums of English Arts Department at some universities, there is the totally domination of the English literature only. Among them, curriculum English Department at Tribhuvan University is the main where is the domination of the English texts and materials is in climax. In B. A. English arts course, there are all the books written by Europeans. There is no any single piece of Nepali writer's text written or translated in English language, prescribed in this course. Likewise, in M. A. English arts annual system, there is only one book namely Nepal Studies that has tried to cover Nepali literature translated and written in English. But in M. A. English semester system program there is just only one piece of Nepali writer's novel, namely Palpasa Cafe written by Narayan Wagle that is translated into English language. There are many books written in English or translated into English language by Nepali writer, available in Nepal but they are not prescribed in the curriculum of English Department at Tribhuvn University, which is very painful experience for some students as well as teachers.

\section{Politics of Neo-colonization in ELT}

English Language teaching methods are playing vital role to colonize in the neo-colonization era. There are some teaching methods that implicitly are playing defensive roles to colonize over developing countries' native language. Among them, the Natural Method or the Direct Method is the best means of neo-colonization. The Natural Method was called the Direct Method later on. Its history is directly connected to the colonialism, because it was introduced in France and Germany, in nineteenth century - is called as the climax of colonization, and became popular in Europe and colonized countries during that time. There is politics on the emergence and implementation of the Natural Method or the Direct Method because Europeans had to teach English language, literature, religion and culture in colonized countries in English that is why they introduced and implemented Natural Method or Direct Method as the best teaching method.

Natural Method or Direct Method has insisted on use of only foreign language in foreign language teaching class. Translation in learner's native language is prohibited in this teaching method. Regarding the Natural Method, Richard and Rodgers writes, that "Sauvur and other believers in the Natural Method argued that a foreign language could be taught without translation or the use of the learner's native language ...." (p.11). In this teaching method, native language is totally avoided while teaching and learning second language. There is no excuse to use native language in the foreign language class. In this way, it has promoted foreign language, literature, religion and culture avoiding the native language, literature, religion, and 
culture. The Direct Method, according to Harmer (2001), "was considered vitally important that only the target language should be used in classroom" (p. 63). It indirectly forces to totally avoid native language and uses foreign language in the classroom which is the easiest way to dominate over native language, literature, religion, and culture. Its implicit intention is highly determined by the colonizing ideology: "Classroom instruction was conducted exclusively in the target language" (Richard \& Rodger, p. 12). It only focuses on target language dominating over native language.

Colonizer highly implemented Natural Method or the Direct Method while teaching their language, literature, religion, and culture in colonized countries. Regarding English language teaching, Thomas Macaulay (1995) in his "Minute on Indian Education" argues that "We must teach them some foreign language" (p. 428). Claiming that foreign language should be taught in foreign language, they started to teach their English language, literature, religion, and religion in colonized countries. In the beginning of the colonization mission they taught English language, literature, religion, and culture to the ruling class and higher class people to show that their language, literature, religion, and culture is unique and those ruling and those higher class people should follow their language, literature, religion, and culture. They did so because it was their politics to convince ordinary people that they should follow their language, literature, religion and culture which is unique. Later on they started to teach English language, literature, religion, and culture to those people who were interested to study English language, literature, religion and culture. Regarding the use of English language, Macaulay (1995) has disclosed the reality in his "Minute on Indian Education". He writes that "In India, English is the language spoken by the ruling class. It is spoken by the higher class of natives at the seats of Government." (p. 428). Colonizer at first taught their language, literature, religion, and culture to those people who were in power during colonization. They taught them their language, literature, religion, and culture to make them bridge between them and colonized people.

Moreover, in the context of Nepal, because of the means of information and technology, words of English language are dominating over Nepali words day by day. It is surprising that even uneducated people also use some English language words instead of using Nepali words. Among them, "time", "ticket", "bus park", "toilet", "tension", "bore", "remote", "computer", "laptop", "helmet", "book", "copy", "switch off", "freeze", "mobile", "face book", "phone", "recharge", "charger", "battery", "comment", "message", "like", "status", "lighter" are some English language words which are always used by even uneducated people. Nepali forms of these words are not used. These words are dominating over Nepali language words which is the negative impact of English language over Nepali language. One after another, English words are being used in Nepali language which is a form of nascent colonization through the language which is called neo-colonization. 


\section{Conclusion}

To sum up, the concept of globalization is more political which has highlighted by Europeans and Americans after the end of direct colonization. Arguing it is globalization era they are politicizing it and maintaining their former colonial hegemony upon developing countries in the name of advanced science and technology, politics, education, teaching methods, language, literature, culture and financial institutions etc. Globalization is the metamorphosis of a globalization into a neo-colonization through which Europe and America are colonizing developing countries. Europeans and Americans are indirectly colonizing developing countries in the name if education, curriculum, and teaching method even in this era too. Countries seemingly less powerful is suffering from the hangover of colonialism that is supposed to be ended in 1940s to 1990s. Still the colonialism is underway in the human psychology in the name of globalization, localization and glocalization which raises the question regarding the end of colonization. Through these various aspects like, education, curriculum, teaching method, social, economic, cultural as well as scientific development, developed countries are colonizing developing countries implicitly that is why we can say that globalization as a disguised form of neo-colonization which is more politicized; And it is indirectly menifestated in the English language teaching classroom of higher education of Nepal.

\section{References}

Altbach, P. G. (1995). "Literary Colonialism: Books in the Third World". The post-colonial studies reader. eds. Bill Aschcroft, et. al. New York: Routledge, pp. 485-490.

Brennan, T. (2013). "From Development to Globalization: Postcolonial Studies and Globalization Theory". Global literary theory: an anthology. ed. Richard J. Lane. Ed. New York: Routledge. pp.876-887.

Lane, R. J. (2013). Global literary theory: an anthalogy. New York: Routledge.

Macaulay, T. (1995). "Minute on Indian Education." The Post-colonial Studies Reader. Bill Aschcroft, et. al. Eds. New York: Rutledge, pp.428-431.

McLuhan, M. (2013). "Time has Ceased, Space has vanished. We now live in a Global Village". Global literary theory an anthology. Ed. Richard J. Lane. New York: Routledge. pp.167177.

Richards, J. C., \& Theodore, S. R. (2001). Approaches and methods in language teaching. Cambridge: Cambridge University Press.

Thiong'o, N. W. (1995 ). "On the Abolition of the English Department." The Post-colonial studies Reader, eds. Bill Aschcroft, et.al. New York: Rutledge, pp.438-442.

Tyson, L. (2008). Critical theory today: user friendly guide. New Delhi: Sirohi Brothers Pvt. Ltd. 